\title{
Suudi Arabistan-İsrail Örtülü İttifakını Anlamlandırmak
}

\author{
Mehmet Rakipoğlu* \& Menderes Kurt ${ }^{* *}$
}

\section{$\ddot{O} z$}

$\mathrm{Bu}$ çalışma Suudi Arabistan-İsrail arasındaki ilişkilerin tarihsel boyutuna değinerek son dönemdeki yakınlaşma belirtilerini anlamlandırmaya çalışmaktadır. İki ülke resmi düzeyde ilişkilere sahip olmamasına rağmen medyaya yansıdığ kadarıyla birçok noktada örtülü bir işbirliği içerisinde oldukları anlaşılmaktadır. Bu minvalde çalışma, iki aktörün son dönemdeki yakınlaşmasını bölgesel düzendeki değişim üzerinden açıklamaktadır. Bu noktada iki ülkenin yakınlaşmasını ABD’nin bölge politikası sonucu artan İran tehdidini dengeleme, Arap ayaklanmaları sonrası değişen güvenlik mefhumu,siyasal İslam'ın bölgede güçlenmesi ve bölge siyasetinde etkin rol oynaması gibi bölgesel düzende üç önemli parametrenin ortaya çıkması sağlamıştır. Söz konusu üç parametre iki ülkeyi yakınlaştırmıştır.

Anahtar Kelimeler: Suudi Arabistan, İsrail, Bölgesel Düzen, Gizli İttifak, Yakınlaşma

Arş. Gör., Batman Üniversitesi, TR, Uluslararası İlişkiler, orcid.org/0000-0002-6287694,mehmet.rakipoglu@batman.edu.tr

** Doktora Öğrencisi, Sakarya Üniversitesi, TR, Ortadoğu Enstitüsü, orcid.org/00000002-9513-3417, kurtmndrs@gmail.com 


\title{
Understanding the Saudi-Israeli Tacit Alliance
}

\author{
Mehmet Rakipoğlu* \& Menderes Kurt**
}

\begin{abstract}
This study examines the rapprochement between Saudi Arabia and Israel. Despite the fact that both countries do not have offical relations, they are in a tacit alliance regarding many aspects as reflected in the media. In this context, the rapprochement of the two countries is explained by "changes of regional order." The basic argument of the study is that the changes of three parameters in the regional order have brought these two actors closer. First, the ascendance of Iran as a result of US policy towards the Middle East. Second, the notion of changing security after the Arab uprisings. Third, the strengthening of political Islam in the region and its active role in regional politics. These three parameters have caused a Saudi-Israeli rapprochement.
\end{abstract}

Keywords: Saudi Arabia, Israel, Regional Order, Tacit Alignment, Rapprochement

\footnotetext{
* Res. Asst., Batman University, TR, Department of International Relations, orcid. org/0000-0002-6287-694, mehmet.rakipoglu@batman.edu.tr

** PhD Student, Sakarya University, TR, Middle East Institute, orcid.org/0000-00029513 -3417, kurtmndrs@gmail.com
} 


\section{Giriş}

Suudi Arabistan'ın kurucu kralı Abdülaziz el-Suud dönemin Amerika Birleşik Devletleri (ABD) başkanı Dwight D. Eisenhower ile yaptığı ikili görüşmede şu ifadeleri kullanmıştı: "Komünistlerin bizim dostumuz olmadığını hatırlamak güzel olsa da, biz Araplar komünizmin çok uzak düşman olduğunu ve İsrail'in kendi arka bahçemizde keskin bir düşman olduğunu fark etmek zorunda kaldık." İsrail'i keskin düşman olarak tanımlayan elSuud o dönem tamamen Suud devletinin mülkü olmayan ARAMCO'dan ${ }^{2}$ İsrail'e petrol satışı yapmayacağına dair yazılı teminat almıştı. ${ }^{3}$ Dolay1sıyla kuruluş yıllarında Suudi Arabistan'ın İsrail'e bakışı keskin ve karşıtlık boyutundaydı. Fakat bu bakış yıllar geçtikçe yumuşamaya başlamıştır. Suudi Arabistan'ın savunma bakanı ve I. Veliahtı olan de facto kral Muhammed bin Selman (bin Selman) bu minvalde birçok açıklama yapmıştır. The Atlantic dergisine verdiği röportajda "İsraillilerin kendi topraklarında yaşama hakkı olduğunu" söylemiş̧ir. ${ }^{4}$ Bin Selman'ın bu minvaldeki eylemleri ve açıklamaları son dönemdeki İsrail-Suudi Arabistan yakınlaşmasının yeni bir işareti olarak görülmektedir. Bu denli yüksek profilden yapılan İsrail yanlısı açıklamalar ve Suudi Arabistan - İsrail yakınlaşması nasıl açıklanabilir? Bu çalışma iki ülke arasındaki ittifakın ve yakınlaşmanın nasıl açıklanabileceğini ve neden şimdi gerçekleştiğini tartışmaktadır. Buna göre bölgesel düzendeki değişimin yarattığ sonuçlar iki aktörü gizli işbirliğine sürüklemiştir. Bu çalışmanın temel iddiası 2010 sonrası Ortadoğu'daki bölgesel düzenin ve siyasetinin parametrelerinin değiştiği ve bu değişimin Suudi Arabistan ve İsrail’i yakınlaştırdığıdır.

İsrail-Suudi Arabistan örtülü yakınlaşaması büyük yankı uyandırması hasebiyle pek çok araştırmaya konu olmuştur. Fakat konu üzerine oluşan literatür bu yakınlaşmanın ABD’nin bölge politikaları sonucu gerçekleş-

1 Eisenhower's Letter to Edward Lee Roy Elson, EM, WHCF, Official File 116-R, 31 Temmuz 1958, Louis Galambos ve Daun Van Ee (der), içinde The Papers of Dwight David Eisenhower, The Presidency: Keeping the Peace, Vol. XIX (Baltimore, MD: The Johns Hopkins University Press, 2001), Letter \#797, 1027.

2 Gawdat Bahgat, Israel and the Persian Gulf: Retrospect and Prospect (Florida: University of Florida, 2006), 118. ARAMCO Suudi Arabistan'1n milli petrol şirketidir.

3 Rosemarie Said Zahlan, Palestine and the Gulf States (New York: Routledge, 2009), 25 .

$4 \quad$ Jeffrey Goldberg, "Saudi Crown Prince: Iran"s Supreme Leader 'Makes Hitler Look Good," The Atlantic, 2 Nisan 2018. 
tiği üzerinde durmaktadır. Bu çerçevede daha çok literatür Obama dönemi ABD'nin İran politikasından endişe duyan Suudi Arabistan ve İsrail'in İran'1 dengelemek için ittifak kurduğunu iddia etmektedir. ${ }^{5} \mathrm{Bu}$ çalışmaya göre mezkur argümanlar doğru fakat eksiktir. Nitekim Trump dönemi ABD'nin Ortadoğu ve İran politikasındaki radikal değişim söz konusu ittifakı sonlandırmamış aksine ilişkiler daha da derinleşmiştir. Bu noktada bu çalışmanın iddiası literatürden farklılaşarak şu şekilde özetlenebilir: İki ülke arasındaki yakınlaşma ve gizli işbirliği sadece İran'1 dengeleme üzerine inşa edilmemiştir. Bu çalışmaya göre iki ülkeyi yakınlaştıran ABD'nin bölge politikaları, İran'ın nüfuzunun artması, Arap ayaklanmaları sonrası bölgede mobilize olmasıyla siyasal İslam'ın temsilcisi Müslüman Kardeşler'in (İhvan) yükselişi ve radikal örgütlerin güçlenişiyle güvenliğin değişimi gibi birçok parametreden oluşan değişen bölgesel düzen ve jeopolitiktir.

Arap ayaklanmaları sonrası bölgesel jeopolitik ve düzende radikal değişimler meydana gelmiş ve siyasal kutuplaşmalar daha belirgin hale gelmiştir. Yaşanan bu gelişmeler bölgesel aktörler açısından yeni ittifaklar ve bloklaşmalar ortaya çıkarmıştır. Bu bağlamda her ne kadar aralarında diplomatik ilişkiler tesis edilmemiş olsa da Suudi Arabistan ve İsrail değişen bölgesel düzen ve jeopolitik karşısında aynı blokta yer almıştır. İdeolojik ve kimliksel aidiyetlerin birçok kez uluslararası ilişkilerde etkisiz kaldığı hipotezini doğrulayan iki ülke arasındaki bu yakınlaşma ve gizliden yürütülen işbirliği uluslararası ilişkiler disiplinindeki realist teorinin temel varsayımları ile açıklanabilir. Buna göre uluslararası politika aktörler arası

Ceyhun Çiçekçi, Arap Baharı Sonrası İsrail Dış Politikası: Kavram, Bağlam, Pratikve Kuram (İstanbul: Kriter, 2018), 86-91; Jacob Abadi, "Saudi Arabia's rapprochement with Israel: the national security imperativess," Middle Eastern Studies 55, no.3 (2019), Uzi Rabi ve Chelsi Mueller, "The Gulf Arab states and Israel since 1967: from 'no negotiation' to tacit cooperation," British Journal of Middle Eastern Studies 44, no. 4 (2017); Ozan Örmeci, "İsrail-Suudi Arabistan Yakınlaşması Gerçeğe Dönüşebilir Mi? Yapısalc1 Realist Bir Analiz," International Journal of Economics, Administrative and Social Sciences (IJEASS) 1, no.1 (Aralık 2018); Gawdat Bahgat, Israel and the Persian Gulf: Retrospect and Prospect (University of Florida, 2006); Rosemarie Said Zahlan, Palestine and the Gulf States (New York: Routledge, 2009); Rene Rieger, "Saudi Arabia's Relations with Israel and Palestine," içinde Saudi Foreign Policy: Conflict and Cooperation, der. Partrick, N. (London: I.B. Tauris, 2016); Joshua Teitelbaum, "Saudi-Israeli Relations: Balancing Legitimacy and Security," BESA Center Perspectives, Paper no. 228 (17 Aralık 2013); Ian Black, "Just Below The Surface: Israel the Arab Gulf States and the Limits of Cooperation," LSE Middle East Centre Report (Mart 2019). 
bir güç mücadelesidir. Bu mücadelede ahlaki değerlerin herhangi bir önemi yoktur. Diğer bir deyişle bu teoriye göre normatif değerler uluslararası ilişkileri belirlemez. Anarşik bir yapıya sahip olan uluslararası sistemde devletler çıkarlarına göre hareket eder. Ayrıca realist teoriye göre devletler ulusal güvenliğe ve devletin bekasina önem atfeder. Söz konusu teorinin zikredilen birkaç unsuru ${ }^{6}$ Suudi Arabistan-İsrail yakınlaşmasını daha anlamlı kılmaktadır. Bu minvalde değişen bölgesel düzende Suudi Arabistan-İsrail arasında gizli işbirliği ortaya çıkmıştır. Söz konusu işbirliği gün geçtikçe daha da açığa çıkmaktadır. Bu çalışma iki ülkenin ne zaman veya ne koşullarda resmi ilişkiler tesis edip/edemeyeceğini tartışmamaktadır. Çalışma iki ülkeyi birbirine yakınlaştıran ve gizli işbirliğine götüren unsurları incelemektedir. ${ }^{7}$ Çalışma ilk olarak iki ülke arasındaki karşılıklı algıları ve ilişkilerin tarihsel arka planını incelenmektedir. İkinci olarak iki ülke arasındaki yakınlaşma belirtileri kronolojik ve analitik bir çerçevede sunulmuştur. Son olarak iki ülkeyi yakınlaştıran bölgesel düzenin değişimi ve parametreleri ele alınmıştır.

\subsection{Karşılıklı Algılar ve Tarihsel Arka Plan}

İsrail kuruluşundan itibaren bölgesel anlamda ittifak kurmaya istekli olmasına rağmen, Filistin meselesi dolayısıyla bölgedeki Arap devletleriyle normal ilişki kurma noktasında başarılı olamamıştır. İsrail ile kimliksel, siyasi ve dini engellerden ötürü normal bir ilişki kuramayan başta Suudi Arabistan olmak üzere diğer Körfez ülkelerinin İsrail ile olan ilişkileri Mısır, Suriye, Lübnan, Ürdün gibi İsrail'e doğrudan sınırdaş olan ülkelerden farklılık arz etmektedir. Suudi Arabistan özelinde konu ele aldığında, İsrail-Suudi Arabistan ilişkilerinin Mısır ve Ürdün'ün İsrail'i kabul süreci gibi sancılı olmaması beklenmektedir. Nitekim iki bölgesel aktör arasında herhangi bir askeri çatışma yaşanmamıştır. Fakat 1970'lerden itibaren Arap coğrafyasında belirleyici olmaya başlayan Körfez'in petrol zengini ülkelerinin bölgeye yönelik politika yapım süreçlerinde ve Filistin me-

Mustafa Aydın, "Uluslararası İlişkilerin “Gerçekçi” Teorisi: Kökeni, Kapsamı, Kritiği,” Uluslararası İlişkiler 1, Say1 1 (Bahar 2004), 33-60.

7 İki ülke arasındaki işbirliğinin gizli biçimde sürdürülmesi daha çok Suudi Arabistan'ın teo-politik yapısı ile alakalıdır. İşbirliğinin açıktan yürütülmesi halinde 1979'da yaşanan Kabe baskını ve daha şiddetli eylemlerin gerçekleşme ihtimali Suudi Arabistan tarafını İsrail ile işbiriliğinde kısıtlamaktadır. 
selesinde daha aktif ve belirleyici rol almaları İsrail ile olan ilişkilerinin normalleşmesini engellemiştir. Her ne kadar normalleşme birkaç bölgesel koşuldan ötürü gerçekleşmemiş olsa da İsrail tarafı Suudi Arabistan'ın bölgesel etkinliği, zengin enerji kaynaklarının varlığı ve iki ülke arasında sıcak çatışmanın yaşanmamasından ötürü Suudi Arabistan ile İsrail arasında diplomatik ilişkilerin kurulması noktasında istekli olmuştur. İsrail için normal ilişkilerin kurulmasında ön koşul olarak ortaya konulabilecek herhangi bir engel bulunmamaktadır. Nitekim çatışma üzerinden kurulan İsrail-Mısır, İsrail-Ürdün ilişkileri tarafların normal ilişki kurulma noktasında karşı1ıklı ön koşulları bulunurken, İsrail ve Suudi Arabistan arasında buna benzer bir durum söz konusu değildir.

Bununla birlikte İsrail açısından Suudi Arabistan, Arap ayaklanmalarına kadarki süreçte İsrail'e düşman olan ülkeleri ve devlet-dışı aktörleri finansal anlamda destekleyen ülke olmuştur. Nitekim Suudi Arabistan'ın 1967 ve 1973 savaşlarında İsrail ile savaşan ülkelere sağladığı finansal destek ve İsrail'i destekleyen ülkelere uyguladığı petrol ambargosu, pek çok ülkenin İsrail ile olan ilişkilerini kesmesine ve tavır değişikliğine gitmesine neden olmuştur. Ayrıca 1973 petrol ambargosunun Avrupa ve Japonya'da yarattığı rahatsızlık ABD'yi İsrail'e "barış için toprak" çerçevesinde baskı yapmaya itmiştir. ${ }^{8}$ Suudi Arabistan'dan kaynaklı bu problemler nedeniyle İsrail'de Suudi Arabistan'a yönelik olumsuz bir bakış oluşmuştur. Yine de İsrail'in Suudi Arabistan'a bakışı Irak, İran ve Suriye'ye olan bakışından önemli düzeyde farklılaşmaktadır. İsrail için Suudi Arabistan, 1981ve 2002'deki belli şartlar karşıllı̆ında barış planları sunan 1lımlı ve doğrudan tehdit oluşturmayan düşman kategorisinde yer almaktadır. ${ }^{9}$ Kısacası, Suudi Arabistan'ın İslami kimliği, İsrail'e düşman devlet ve devlet-dışı aktörleri desteklemesi gibi "olumsuz" özellikleri barındırmasına rağmen, ABD ile olan yakın müttefiklik ilişkisi, İsrail'e yönelik doğrudan düşmanlık güden hareketlerde bulunmaması, İsrail-Arap/Filistin barışına yönelik ortaya koyduğu barış planı önerileri, Suudi Arabistan'ı İsrail'in bir numaralı düşmanları listesinin dışında yer almasını sağlamıştır. ${ }^{10}$

Patrick Tyler, A World of Trouble: The White House and the Middle East- from the Cold War to the War of the Terror, (New York: Farrar, Straus and Giroux, 2010), 173175.

9 Gawdat Bahgat, Israel and the Persian Gulf, 115-116, 119-127.

10 Gawdat Bahgat, Israel and the Persian Gulf, 137. 
Suudi Arabistan'ın İsrail'e yönelik bakışı ise dört dinamik ile açıklanabilir. Tarihsel olarak Suudiler İsrail'e karşı çatışmaya yönelik sert ve askeri bir tutumdan ziyade yumuşak ve barışçıl yolla yaklaşmıştır. Suudi Arabistan İsrail ile askeri olarak hiçbir şekilde karşı karşıya çarpışmamıştır. ${ }^{11}$ Ayrıca Suudilerin Arap ordularına gönderdiği asker sayısı ve kapasitesi sembolik olmaktan öteye geçmemiştir. ${ }^{12}$ Bu noktada Suudi rejiminin İsrail'e bakış açısını belirleyen ilk dinamik Suudi Arabistan'ın Soğuk Savaş konjonktüründeki tehdit algısıyla alakalıdır. Suudiler bu dönemde ABD'nin yanında Sovyetlerin karşısında pozisyon almıştır. İsrail her ne kadar ABD'nin müttefiği olsa da Suudiler, siyonizmin bir politik hareket ve sosyalist bir ideoloji arasında yer aldığını belirterek Arap-İsrail çatışmasına ABD-Sovyet rekabetinin bölgesel yansımaları bağlamında yaklaşmıştır. Soğuk Savaş'ın yeni yeni filizlendiği 1948 y1lında kurulan İsrail Suudilere göre komünistateist Sovyetlerin desteği ile kurulmuştur. ${ }^{13}$ Dahası Suudilere göre İsrai1, Sovyetlerin 19. yüzyılın ikinci yarısında Ortadoğu'ya nüfuz etmesini sağlamıştır. ${ }^{14}$ Benzer şekilde 1948 savaşının İsrail tarafından kazanılması muhafazakar Arap rejimlerinin düşmesine ve Misır-Suriye ve Irak gibi radikal pan-Arabist ve Sovyet yanlısı rejimlerin bölgede kök salmasına neden olmuştur. Söz konusu Sovyet yanlısı rejimler Suudi Arabistan'1n rejim güvenliğine doğrudan tehdit oluşturmuştur. İsrail'in saldırgan tutumu Filistinlileri ve Arapları radikalleştirerek onları ABD karşıtlığına ve Sovyet taraftarlığına itmiştir. Bu durum da ABD'nin önemli bir müttefiği olan Suudi Arabistan'ı savunmacı konuma sürüklemiştir. Suudiler ABD'nin İsrail yanlısı politikasından vazgeçmesi için petrolü bir silah ${ }^{15}$ olarak kullanırken, ABD Suudilerin İsrail karşıtı politikasını yumuşatması için girişimlerde bulunmuştur. ${ }^{16}$ Örneğin 1967 Savaşı sonrası Suudi Arabistan'ın ABD ve İsrail karşıtlığının sonlandırılması için ABD Başkanı Johnson, Joseph

11 Dwight D. Eisenhower, The White House Years: Waging Peace, a Personal Account 1956-1961 (New York: Doubleday \& Company, Inc. 1960), 118.

12 Gawdat Bahgat, Israel and the Persian Gulf, 123, 124.

13 Gawdat Bahgat Korany ve Moataz A. Fattah, "Irreconcilable Role-Partners?: Saudi Foreign Policy between the Ulama and the US," içinde The Foreign Policies of Arab States: The Challenge of Globalization, der. Bahgat Korany ve Ali E. Hillal Dessouki, (New York\&Cairo: The American University in Cairo Press, 2008), 391.

14 Gawdat Bahgat, Israel and the Persian Gulf, 115-121.

15 "The Gulf States and Israeli- Palestinian Conflict Resolution," Baker Institute Policy Report, Rapor 61 (Eylül 2014), 3.

16 Uzi Rabi ve Chelsi Mueller, "The Gulf Arab states and Israel," 580. 
Sisco ve George Ball ${ }^{17}$ gibi iki önemli ismi Ortadoğu turuna göndermiştir. Kudüs, Amman, Beyrut ve Cidde'ye giden ABD temsilcileri dönemin Suudi Arabistan Dışişleri Bakanı Ömer Sakkaf ve kralın danışmanı Raşit Faron ile kralın İsrail karşıtlığının son bulunması amacıyla görüşme gerçekleştirmiştir. ${ }^{18}$

Suudi Arabistan'ın İsrail'e bakışını etkileyen ikinci dinamik ise dini ve kültürel faktörlerdir. İslami yorumlar kaynaklı olan bu faktörler, Suudilerin İsrail'i Arap ve Müslüman toprakları işgal etme niyetinde olan düşman/ işgalci bir varlık olarak tanımlamasında ve İsrail karşıtı bir pozisyon almasında etkli olmuştur. ${ }^{19}$ Üçüncü dinamik İsrail'in 1967'den beri İslam'ın üçüncü kutsal şehri olan Kudüs'ü kontrol ediyor olmasıdır. "Mekke ve Medine'nin hizmetkarı" olduğu iddiasında bulunan Suud rejimi, mezkur şehirlerden sonra İslam'daki üçüncü kutsal mescidi barındıran Kudüs'e ve şehrin Müslümanlar tarafından kontrol edilmesine büyük önem atfetmektedir. Dördüncü dinamik Filistin meselesinin Arap ve Müslüman coğrafyada merkezi konuma sahip olması ve Filistinli işçilerin Suudi Arabistan dahil Körfez monarşilerindeki varlı $\breve{g}^{20}$ Suudi Arabistan'ın İsrail'e bakışını etkilemiştir.

Suudi Arabistan bağımsızlığını elde ettiği dönemde Haşimi monarşisinin bölgede devletleşmesini tehdit olarak algılaması dolayısıyla İsrail'in kuruluşuna nispeten göz yummuştur. Öte yandan 1948 Savaşı'nda ise Suudiler İsrail ile doğrudan savaş meydanında karşı karşıya gelmemiştir. ${ }^{21}$ 1967 savaşı da Suudilerin savaşın gidişatında etkisiz pozisyon aldığı bir diğer Arap-İsrail savaşıdır. Benzer şekilde 1973 (Yom Kippur) Savaşı'nda da Suudi Arabistan'ın desteği Araplar tarafından yeterli bulunmamıştır. Bunun yanında bölgede Arap milliyetçiliğini merkeze alarak revizyonist politikalar üreten Cemal Abdünnasır Suudi Arabistan monarşisine tehdit

17 Joseph Sisco ABD Başkanı Johnson döneminde dışişleri bakanı yardımcısıdır. George Ball ise dönemin dışişleri bakanlığı müsteşarıdır.

18 Rosemarie Said Zahlan, Palestine and the Gulf States, 38.

19 William B. Quandt, Saudi Arabia in the 1980s: Foreign Policy, Security, and Oil (Washington: Brookings Institution Press,1981), 31.

20 Baker Institute Policy Report, 2; Jaroslav Bureš, Main Characteristic and Development Trends of Migration in the Arab World (Prague: Institute of International Relations, 2008), 102-104.

21 Simha Flapan, The Birth of Israel: Myths and Realities (New York: Pantheon Books), 1987, 122. 
oluşturmuştur. Bu minvalde Yemen'deki iç savaşa dahil olan Suudi Arabistan İsrail ile işbirliğine gitmiştir. ${ }^{22}$ İki ülke arasındaki işbirliği ilk defa 1964 yılında net şekilde ortaya koyulmuştu. Kraliyet yanlısı müttefikinin askeri ve ekonomik anlamda desteklenmesi için Suudi Arabistan, İsrail istihbarat servisi Mossad ile bir dizi görüşmelere başlamıştı. Mivtza Rotev (Operation Sauce) olarak bilinen operasyonla kraliyet yanlıları İsrail'den yardım aldı. Golan Tepeleri başta olmak üzere birçok stratejik noktayı kaybetmemek ve Arapları kendisine karşı tek yumruk olarak görmek istemeyen Tel Aviv yönetimi Nasır'ın yönettiği Mısır'ı ortadan kaldırmak için Suudilerle işbirliği yapmıştı. ${ }^{23}$ Nasır'ın ölümü ve 1973 savaşının kaybedilmesiyle birlikte Araplar arasında başlayan liderlik rekabetinde finansal gücüyle Suudi Arabistan ön plana çıkmıştır. 1979'daki İran Devrimi ve Irak-İran Savaşı sonrası oluşan bölgesel konjonktür Suudi Arabistan ve İsrail tarafından benzer perspektiften okunmuştur. Bu minvalde iki ülkeinin işbirliği halinde oldukları ${ }^{24}$ ve yakınlaştıkları iddia edilmiştir. ${ }^{25} \mathrm{Bu}$ anlamda 1980'li y1llarda ve devam eden süreçte iki ülke birbirine yönelik 1lımlı politikalar izlemeye başlamıştır.

\subsection{Yakınlaşma Belirtileri}

Ağustos 1981 tarihinde Suudi veliaht Fahd'ın önerdiği barış planı Suudi Arabistan'ın İsrail politikasındaki radikal değişimin en önemli işaretiydi. Bu planla birlikte Riyad yönetimi İsrail'i tanımama politikasından vazgeçmiştir. ${ }^{26} 1991$ 'deki Madrid Konferası sonrası dönemde iki ülke arasındaki yakınlaşma çabaları bir kademe daha ilerlemiştir. Söz konusu konferansta ilk kez İsrailli yetkililer görüşmelere gözlemci olarak katılan Körfez yetkilileri ile resmi olarak biraraya gelmiştir. ${ }^{27} 1993$ 'te Oslo Anlaşmasının imzalanması sonrasında da Suudi Arabistan dahil Körfez ülkeleri İsrail ile

22 Asher Orkaby, "Rivals with Benefits: Israel and Saudi Arabia's Secret History of Cooperation", Foreign Affairs, 13 Mart 2015.

23 Joseph Mann, "The Syrian Neo-Bacth Regime and the Kingdom of Saudi Arabia," Middle Eastern Studies 42, 5 Eylül 2006, 764.

24 Gawdat Bahgat, Israel and the Persian Gulf, 125.

25 Uzi Rabi ve Chelsi Mueller, "The Gulf Arab states and Israel," 581.

26 Yoel Guzansky ve Sigurd Neubauer, "Israel and Saudi Arabia: A Changing Region, a Possible Partnership," The National Interest, 24 Temmuz 2014.

27 Uzi Rabi ve Chelsi Mueller, "The Gulf Arab states and Israel," 583. 
ticaret yapan firmalara yönelik olan yasağ kaldırmıştır. ${ }^{28}$ Kral Abdullah'ın 2002'de sunduğu barış planı ${ }^{29}$ Suudi Arabistan'ın İsrail'i tanımak istediğini ortaya koyan en net belgedir. Her ne kadar Abdullah'ın planı İsrail tarafindan kabul edilmese de Arap Birliği'nin 1967'deki Hartum zirvesinde al1nan kararların radikal şekilde değiştiğini göstermiştir. Bu zirveyle birlikte Suudiler Misır, Ürdün, Lübnan, Filistin, Suriye gibi İsrail ile mücadeledeki ön cephe devletlerini (front-line states) finansal yönden desteklemiştir. ${ }^{30}$

2003 y1lında Saddam Hüseyin sonrası Irak'ta İran'ın bölgede başat aktör haline gelmesi de iki aktörü birbirine yakınlaştırmıştır. ${ }^{31}$ Öte yandan İran'ın bölgesel nüfuzunun en zirvede olduğu 2006 yılındaki İsrail-Hizbullah savaşı, Suudi yetkililer tarafından bölgesel güç dengesi ve düzene meydan okuyan bir gelişme olarak görülmüştür. Bu konjonktürde Suudi Arabistan Hizbullah'a karşı İsrail'i desteklemiştir. ${ }^{32}$ 2007'deki Annapolis barış planı da Suudi Arabistan'ın Filistin meselesinde aktif rol aldığını ve İsrail'e karşı daha orta yollu politikalar izlediğini göstermiştir. ${ }^{33}$ İran'ın 2009'da kendi uydusunu üretmesi ve bununla bağlantılı olarak nükleer balistik füze projesini gündeme getirmesi Suudi Arabistan-İsrail arasındaki yakınlaşmayı artırmıştır. İngiliz Sunday Times'ın ${ }^{34}$ iddiasına göre Suudi Arabistan İran'ın nükleer tesislerine saldırması için İsrail'e hava sahas1$\mathrm{n}$ 1 açmıştır. ${ }^{35}$ Öte yandan İsrail İsrailli güvenlik firmaları Suudi Arabistan, Bahreyn ve BAE gibi Körfez ülkelerine hizmet ve teknolojik destek sağlamıştır. Örneğin 2012 y1lında İran'ın Suudi Arabistan'ın milli petrol şirketi olan ARAMCO’ya ait 40.000 bilgisayarı hacklemesinde İsrailli ileri

28 Söz konusu yasak Arap Ligi tarafından 1948 yılında yürürlüğe girmiştir. Örgütün üyesi olan Suudi Arabistan da bu yasağa uygulamıştır. Fakat Suudilerin bu yasağı hayata geçirmediğini dile getirenlerde mevcuttur. Martin A.Weiss, "Arab League Boycott of Israel," CRS Report, 25 Ağustos 2017, 2.

29 Mai Yamani, “Two Faces of Saudi Arabia,” Survival 50, no. 1 (2008), 143.

30 Rosemarie Said Zahlan, Palestine and the Gulf States, 37.

31 Uzi Rabi ve Chelsi Mueller, "The Gulf Arab states and Israel," 578.

32 "Saudi supported Israel against Hezbollah during 2006 war", The Middle East Monitor, 16 Şubat 2019.

33 Joseph Kostiner, "Saudi Arabia and the Arab-Israeli Peace Process: The Fluctuation of Regional Coordination," British Journal of Middle Eastern Studies 36, no.3, Aralık 2009, 417-429.

34 Joshua Teitelbaum, "Saudi-Israeli Relations," 2.

35 "Israel said to be working with Saudi Arabia on Iran strike plan," Times of Israel, 17 Ekim 2013. 
düzeyli şirketler söz konusu sorunu çözmüştür. Aynı yıl Suudi Arabistan İsrail'den de ortağı olduğu AGT firmasından IntuView isimli bir yazılım satın almıştır. ${ }^{36} 2013$ yılında Suudi Arabistan'ın İsrail ile savunma işbirliği yaptığ ${ }_{1}$ iddia edilmiştir. ${ }^{37}$

Öte yandan İran'ın nükleer programı ve Hamas desteği ile Filistin'de, Haşdi Şabi desteği ile Irak'ta, Hizbullah ile Lübnan'da ve birçok politik-askeri-ekonomik aktörle Suriye'de artan varlığına karşı Suudi Arabistan İsrail arasındaki örtülü (tacit) işbirliğini derinleştirmiştir. ${ }^{38} 14$ Temmuz 2015'te BMGK üyesi 5 ülke ve Almanya ile İran arasında Ortak Kapsamlı Eylem Planı olarak bilinen anlaşma imzalamıştır.Anlaşma Suudi Arabistan ve İsrail açısından ortak kaygılarla karşılanmıştır. ${ }^{39}$

Bu minvalde Suudi Arabistan'ın eski İstihbarat başkanı Prens Türki alFaysal İsrail gazetesi Haaretz'e bir röportaj vermiştir. Röportajda Faysal her ne kadar hayata geçirilmesi zor olsa da iki devletli çözümün hayata geçirelebilir olduğunu belirtmiştir. Benzer şekilde Haaretz'e yazdığ 1 açık görüş yazısında "Hayal ediyorum. Bir gün Riyad'dan direkt Kudüs'e uçuyorum. Bir taksiyle veya otobüsle Mescid-i Aksa'ya gidiyorum ve Cuma namazı kılıyorum. Sonra da Ağlama Duvarı'nı ve Kutsal Kabir Kilisesi'ni ziyaret ediyorum" ifadelerini kullanarak İsrail'e zeytin dalı uzatmış ve iki ülke arasındaki barışı ne kadar istediğini ortaya koymuştur. ${ }^{40}$ Aynı yıl Suudi emekli General Enver Aşki İsrail Dışişleri Bakanlığı Müsteşarı Dore Gold ile bir toplantıda bir araya gelerek yıllardır zaten gizlice görüşen iki ülkenin artık ilişkilerini açık etmeye karar verdiklerini açıklamıştır. Türki el-Faysal 2016 yılında da İsrail yanlısı bir düşünce kuruluşunun bir toplantısında İsrailli General Yaakov Amidror'la bir araya gelmiş ve ortak 1lımlı mesajlar verilmiştir. Aynı yıl Temmuz ayı Enver Aşki beraberinde bir Suudi heyetiyle İsrail'i ziyaret etmiş ve İsrail Parlamentosu Knesset'i ziyaret ederek dostluk ve barış mesajları vermiştir. 2016 yılı Ağustos ayında, İsrailli eski Bakan ve haham Michael Melchior, "Yakında vatandaşlarımız Suudi Arabistan'ı ziyaret edebilecek" şeklinde iddialı bir açıklama yap-

\footnotetext{
36 Uzi Rabi ve Chelsi Mueller, "The Gulf Arab states and Israel," 589.

37 Joshua Teitelbaum, 2.

38 "Ex-Saudi intelligence chief reveals secret Israel-Saudi relations," The Middle East Monitor, 11 Şubat 2019.

39 "Why Saudi Arabia and Israel oppose Iran nuclear deal," Al Jazeera, 14 Nisan 2015.

40 Guzansky ve Neubauer, "Israel and Saudi Arabia."
} 
mıştır. Ekim 2017'de Suudi Arabistan eski adalet bakanı Muhammed Abdülkerim el-İssa ve yine Suudi Arabistan'ın eski eğitim bakanı Halid bin Muhammed el-Angari Paris'te bir sinagogu ziyaret ederek İsrail'e olumlu 1şık yakmıştır. ${ }^{41}$

2017 y1lı sonlarında Suudi Arabistan'ın Elaph gazetesine verdiği röportajda İsrail Genelkurmay Başkanı Gadi Eizenkot, Suudi Arabistan başta olmak üzere tüm 1lımlı Arap devletleriyle İran'1 dengelemek için istihbarat paylaşımına hazır olduklarını açıklamıştır. ${ }^{42}$ Yine 2017 yılında İsrail başbakanı Netanyahu'nun Arap ülkeleri ile İsrail arasındaki ilişkilerin hiç olmadığ kadar iyi dediği bir zaman diliminde Voice of Israel adlı radyonun iddiasını göre ${ }^{43}$ ismi belirlenemeyen bir Suudi prens İsrail'e gizli bir ziyaret gerçekleştirmiştir. ${ }^{44} 2018$ yılı Mayıs ayında Suudi Arabistan 70 yıllık yasağ delerek Air India firmasına Yeni Delhi-Tel Aviv arası uçuşlarında Suudi hava sahasını kullanma izni tanımıştır. 2018 yılı Nisan ayında, bin Selman, "İsrail ve Filistinlilerin kendi devletlerini kurmaya hakları vardır" diyerek, Suudi Arabistan tarihinde ilk kez açık bir şekilde İsrail'i tanıma sinyalleri vermiştir. ${ }^{45}$ Haziran 2017'deki Katar krizinde Suudi Arabistan İsrailli yazılım firmasından yardım almıştır. ${ }^{46}$ Aynı aylarda İsrail Tel Aviv'den Suudi Arabistan'a hacılar için direk uçuş girişiminde bulunmuştur. Son olarak İsrail basını bin Selman hakkında övgü dolu yazılar yayınlayarak ${ }^{47}$ bin Selman yönetiminde iki ülkenin daha yakın ilişkiler geliştirebileceğinin sinyallerini vermiştir.

2000'ler sonrası yakınlaşma belirtilerine bakıldığında Suudi Arabistan ve İsrail'in ilişkileri daha açık yürütmeye istekli oldukları söylenebilir. Geçmişte iki ülkenin yakınlaşmaları çoğunlukla geçici ve anlık tehlikeler karşısında şekillendiği veya tehditi ortadan kaldırma amaçlı olduğu görül-

$41 \quad$ Elliot Abrams, "The Saudis and Israel-Again," Council on Foreign Relations, 23 Kasim 2017.

42 Amos Harel, "Israeli Military Chief Gives Unprecedented Interview to Saudi," Haaretz, 17 Kasım 2017.

43 "Saudi prince in 'secret meeting' with Israeli officials," The New Arab, 10 Eylül 2017.

44 "Saudi prince paid secret visit to Israel: Broadcaster," Anadolu Agency, 8 Ağustos 2017.

45 Ozan Örmeci, “İsrail-Suudi Arabistan Yakınlaşması,” 77-80.

46 "Israeli Software Helped Saudis Spy on Khashoggi, Lawsuit Says," The New York Times, 2 Aralık 2018.

47 “İsrail basını Veliaht Prens Bin Selman`a methiyeler dizdi," Sabah, 23 Ekim 2018. 
mektedir. Fakat Arap ayaklanmaları sonrası bölgesel düzendeki değişimler anlık tehlikeler yaratmak yerine bölgede iki ülke için kalıcı tehditler oluşturmaya başlamıştır. Bu tehditler, iki ülke için sadece geçici olarak yakınlaşmanın ötesinde, ilişkileri var olan tehditlere karşı daha kurumsal bir zemine oturtma ve bölgede kendi lehlerine bir statüko oluşturma ihtiyac1nı doğurmaktadır. Bu nedenle geçmişte kurulan kısa süreli ilişkiler yerine daha uzun ve kurumsal ilişkiler tesis etmeye yönelik hamleler atılmaktadır.

\section{Yeni Bölgesel Düzen ve İsrail-Suudi Arabistan Yakınlaşması}

İsrail ve Suudi Arabistan yakınlaşmasının neden şimdi gerçekleştiği sorusuna cevaben bu çalışmanın temel iddiası değişen bölgesel düzenin yarattığ1 sonuçların İsrail ve Suudi Arabistan yakınlaşmasını mümkün kıldığıdır. Araştırmanın sorusuna cevaben ortaya konulan bu iddianın kanıtlanması için öncelikle yapılması gereken bölgesel düzenden kastedilenin ne olduğudur. Dolayısıyla "Bölgesel düzen nasıl tanımlanabilir?" sorusuna cevap verilmelidir. Bu çerçevede Ortadoğu'da bölgesel düzenden bahsediliyorsa, bölgenin kendi tanımlaması problemli olduğu için bölgesel düzeni tanımlamak haliyle problem teşkil etmektedir. Söz konusu problemin aşılması ve bölgesel düzeni iyi ortaya koymak için hangi bölgeden bahsedildiği ve bu bölgeyi nasıl tanımlandığı önemlidir. Ortadoğu isimlendirmesi ve tanımlaması Batılılar tarafından yapıldı̆̆ 1 için bölgenin yapay bir oluşum olduğu araştırmacılar tarafından kabul edilmektedir. Bölgenin sınırları, hangi alanı kapsadığı, hangi devletleri içerdiği, tanımlamasını hangi olguya (tarihsel, coğrafi, kültürel vb.) göre yapılacağı kişiden kişiye, bölgeden bölgeye farklılık göstermektedir. ${ }^{48}$ Bölgenin tanımlaması üzerine yapılan tartışmaların karmaşasına girmeden bir bölgesel düzen tanımlaması yapmak için tanımlama üzerine yapılan yorumların içerisinden genel veya ortalama bir tanımlamayı verili kabul edip onun üzerinden hareket edilmelidir. Bu çerçevede bu çalışmada Ortadoğu denildiğinde; Mağrib, Maşrık (Levant) ve Körfez alt bölgelerinden oluşan, coğrafi sınırları Fas'tan İran'a

48 Ortadoğu bölgesinin tanımlaması ve coğrafik sınırlarının nasıl belirlenmesine dair yapılan tartışmalar için bkz. Nikki R. Kiddie, "Is There a Middle East?," International Journal of Middle East Studies 4, no. 3 (Temmuz 1973): 255-271; James P. Piscatori ve R.K. Ramazani, "The Middle East," içinde Comparative Regional Systems: West and East Euorope, Nort America, The Middle East, and Developing Countries, der. Werner J. Feld ve Gavin Boyd (New York: Pergamon Press, 1980): 274-299. 
uzanan, içerisinde Arap devletlerini ve İran, Türkiye ve İsrail gibi Arap olmayan üç devleti içeren, Arap kültürü, İslami kültürü ve Osmanlı ve Safevi İmparatorluklarının tarihsel mirasının hakim olduğu bölge kastedilmektedir. Tanımlanan bölgenin farklılıkları olmakla birlikte dışarıdan bir bütün olarak algılanması, işbirlikleri, çatışmaları, tarihsel gelişimleri, dil ve din ve ideolojik paylaşımları, benzer olay ve olgulardan etkilenmeleri göz önüne alınarak bir bütün olarak ele alınmaktadır.

Ortadoğu'ya dair bu verili tanımlamayı yaptıktan sonra bölgesel düzen şöyle tanımlanabilir: "içsel ve dışsal olarak kendine özgü bir arena olarak tanınan... genel olarak iki aktör tarafından yaratılan ve sürdürülen nispeten düzenli ve yoğun etkileşim biçimleri. ${ }^{~}{ }^{49}$ Bir diğer ifadeyle bölgesel düzen, belirli bir bölgenin aktörleri arasındaki müzakereler, ortak varsayım, normlar ve kurumların oluşturduğu çeşitli etkileşim biçimleri yani bölgeyi oluşturan dinamikler veya dinamikler bütünüdür. ${ }^{50} \mathrm{Bu}$ çerçevede düzen üç olgu üzerinden tanımlanabilir: yapı (structure), süreç (process) ve odak (focus). Yapı, bölgedeki devletler arasındaki ilişkinin baskın modeller/biçimleri (dominant patterns) olarak tanımlanabilir. Süreç, bu modeller içerisinde ilişkilerin doğası; ittifaklar, koalisyonlar, cepheler ve işbirliği, rekabet, çatışmalar gibi bölgenin yapısal özellikleridir. Odak ise belli ilişkilerdeki belli hakim konuların derecesi, bölge dinamiklerinin üzerinde şekillendiği merkezdir. Dolayısıyla odak, sistem yapısının ana özelliğini yansıtır. ${ }^{51}$ Odağın nasıl belirleneceği araştırmacılar arasında farklılaşmaktadır. Fakat bu çalışmada Tareq Ismael'in belirlediği üzere bölge siyasetinde öne çıkan konuları ve bölge siyasetini şekillendiren olgular olarak ele alınmaktadır. Odak tek bir konu veya olgu olabileceği gibi pek çok konu ve olgudan da oluşabilir. Bölgesel düzendeki değişimi daha net ortaya koyabilmek için tarihsel bir yol izlenecek ve çoğunlukla Ortadoğu'da bölgesel düzeni tarihsel olarak ele alan Tareq Ismail, Raymond Hinnebush, Paul Salem ve Louise Fawcett gibi araştırmacıların çalışmalarından yararlanılacaktır. Bu çerçevede çalışma bölgesel düzendeki değişimi tarihsel

49 Tareq Y. Ismael, "Regional Dynamics and International Relation in the Middle East," içinde International Relations of the Contemporary Middle East: A Study in World Politics, der. Tareq Y. Ismael (Syracuse University Press, 1986), 41.

50 Interregnum: The Regional Order in the Middle East and Nort Africa: After 2011, MENARA Final Reports, no. 1 (Şubat 2019), 6.

51 Tareq Y. Ismael, International Relations of the Contemporary Middle East, 41-42. 
olarak ele almakla birlikte daha çok 2000 sonrası oluşan "Yeni Ortadoğu" düzenine odaklanmaktadır.

Yeni Ortadoğu'yu anlamak için “eski”nin ne olduğu ve nasıl işlediği, nasıl bir fark oluştuğunu görmemiz açısından önemlidir. 2000 öncesi Eski Ortadoğu düzeni üç başlık altında ele alınabilir: Kolonyal Dönem (1920-1955), Arap Milliyetçiliğini Yükselişi ve Düşüşü: Nasır Çağı (1956-1970), Arap Üçgeninden Ayrı Barışa: Çok Merkezli Arap Dünyası (1970-2000). ${ }^{52}$

Kolonyal Dönem, Osmanlı Devleti'nin I. Dünya Savaşı sonrası yıkılmasıyla, Avrupalılar tarafindan Vestfalya devletler sistemine göre yeniden düzenlenen bölgeyi ifade etmektedir. Bu dönem bölgede ulus-devlet olarak dizayn edilen devletlerin her biri halen Avrupalı devletler tarafindan kontrol edilmektedir. Bu nedenle bu dönem çoğunlukla sistem öncesi kolonyal dönem olarak adlandırılır. Fakat bu dönem II. Dünya Savaşı ile birlikte değişmeye başlamıştır. Savaş sonrası nispeten bağımsızlığını kazanan Arap devletleri Batı egemenliğini zayıflatmıştır. Böylelikle devlet sisteminin oluşmaya başladığı yarı bağımsız ve anti-emperyal bir sistem ortaya çıkmıştır. Nitekim bu dönem Arap devletlerinin Arap Ligi etrafında işbirliği geliştirmeye çalıştığı, Arap-İsrail çatışması üzerinden Arap milliyetçiliğinin bölgesel kimliği ve politikayı belirlediği bir dönemdir. ${ }^{53} 1945-56$ arası olarak tarihlendirilen bu dönemde I. Arap-İsrail Savaşı'nın kaybedilmesiyle Arap milliyetçiliğinin ve anti-emperyalizmin yükselişi gibi olay ve olguların tetiklemesi sonucu olarak Cemal Abdünnasır, 1956 Süveyş Krizi ile birlikte Arap milliyetçiliğinin sesi ve bölgesel ana düzenleyici olarak öne çıkmıştır. 1956-1970 arası dönem çoğunlukla Nasır'ın liderliğini yaptığı Arap birliği ve Arap milliyetçiliği ideolojisi üzerine kurulan bir yapı üzerinde bölge politikasının odağını Arap-İsrail çatışmasının oluşturduğu bir bölgesel düzen hâkimdir (Arap Milliyetçiliğini Yükselişi ve Düşüşü). Arap milliyetçiliği veya Nasırizm'in merkezi rolü bölge politikasında ve problemlerin üzerinden gelmek amacıyla bölge insanlarını ve devletlerini ortak hareket ettirmesi ve diş müdahaleyi nispeten aza indirerek bölgenin kendi

52 Bölümlendirmeye dair ayrıntılı bilgi için bkz. Tareq Y. Ismael, International Relations of the Contemporary Middle East, 41-42; Raymond Hinnebusch, "The Middle East Regional System," içinde The Foreign Policies of Middle East States, der. Raymond Hinnebusch ve Anoushiravan Ehteshami (London: Lynne Rienner Publishers, 2002).

53 Tareq Y. Ismael, International Relations of the Contemporary Middle East, 43, Hinnebusch, "The Middle East Regional System,” 34-35. 
kaderini kontrol etmesini sağlamasıdır. ${ }^{54}$ Fakat 1967 yenilgisi ve 1970 'de Nasır'ın ölmesinin ardından Arap milliyetçiliği ideolojisi gücünü kaybetmiş, bölgede lider boşluğu doğmuş, güç dengesi değişmiş ve yeni bölgesel ekonomi politiği doğmuştur. Bu olguların hepsinin sonucunda ise bölgede çok merkezli, parçalı bir bölgesel işbirliği düzeni oluşmuştur. (Arap $\ddot{U} c ̧$ geninden Ayrı Barışa: Çok Merkezli Arap Dünyası). ${ }^{55}$ Bunun sonucunda bölgenin merkezi odağı Arap-İsrail çatışması etkisini kaybetmiş ve Batı Sahra, İran Devrimi, Irak-İran Savaşı, Etiyopya-Somali çatışması, Lübnan İç Savaşı gibi yeni odaklar ortaya çıkmıştır. Bu dönem bölgenin ortak odak çerçevesinde hareket etmek yerine yerel işbirliği veya çatışmalar etrafında odaklandığı çok merkezli ve çok odaklı bir yapı hâkimdir. Bölgesel düzendeki bu parçalanma en çok yeni ekonomi politik sayesinde yükselen Körfez bölgesi ve İsrail'e fayda sağlamıştır. Ayrıca bölgesel düzendeki çok merkezlilik ve çok odaklılık, diş etkene karşıllık ortak direnç sağlayan Arap işbirliği olgusunu zayıflatmış ve bölgeyi dış müdahalelere daha açık hale gelmiştir. $^{56}$

Nasır'ın ölümü ile birlikte Mısır'ın liderlik koltuğundan düşmesi sonucu bölge politikalarında Misır, Suudi Arabistan ve Suriye'nin etkin olduğu üçlü Arap koalisyonu ortaya çıkmıştır. Sedat, Faysal ve Esad arasında bölüştürülen liderlik 1973 Savaşı, 1973 Petrol Ambargosu ve Misır-İsrail barışı sonucu yeniden değişmiştir. ${ }^{57}$ Nasır' dan sonra Mısır devlet başkanı olan Enver Sedat'ın daha 1lımlı ve Batı yanlısı bir kişiliğe sahip olmas1 aynı zamanda Mısır'ın ekonomik ve askeri gücünün bölgesel liderliği sürdürme noktasında yeterli gelmemeye başlaması bölgede önemli bir güç boşluğu yaratmıştır. Bu çerçevede Mısır'dan boşalan lider koltuğuna milliyetçi Libya, Suriye, Irak ve finansal gücünü 1973 petrol ambargosu ile kanıtlayan Körfez ülkeleri aday olmuştur. Mısır'dan boşalan lider boşluğu üzerine yapılan mücadelede ise finans güçleri ve ABD ile olan yakın ilişkileri sayesinde Körfez ülkeleri galip çıkmıştır. Nitekim Soğuk Savaşın bitmesi ile Arap milliyetçiliği kampında yer alan ülkeler en büyük destekçilerini kaybetmiştir. Aynı zamanda Sovyetler Birliği'nin dağılması ve Körfez Savaşı ile gücünü kanıtlayan ABD'nin dünyada tek hegemon

\footnotetext{
54 Raymond Hinnebusch, "The Middle East Regional System," 35-40.

55 Tareq Y. Ismael, International Relations of the Contemporary Middle East, 59.

56 Tareq Y. Ismael, International Relations of the Contemporary Middle East, 59-64.

57 Raymond Hinnebusch, "The Middle East Regional System," 41-42.
} 
olarak yükselmesi, Irak, Suriye ve Libya gibi ülkelerin bölgesel gücünü s1nırlandırmıştır. Bölgesel anlamda ortaya çıkan diğer önemli gelişmeler ise 1979'daki Mısır-İsrail ile 1994'teki Ürdün-İsrail anlaşmalarıdır. Yaşanan bu gelişmeler Filistin meselesinin bölgedeki merkez çekirdek olma özelliğini kaybetmesini sağlamıştır. İsrail-Arap çatışması sonucunda Mısır'ın geri çekilmesi, Sovyetlerin dağılması ve ABD hegemonyasında liberal değerlerin ön plana çıktığı yeni dönemde Arap milliyetçiliği etkisini yitirmiştir. Buna mukabil 1979 İran Devrimi, Sovyetlerin Afganistan'ı işgal etmesi ve Suudi Arabistan ve Körfez ülkelerinin bölgede güç kazanması ile birlikte İslami ideoloji ve İslami hareketler güç kazanmıştır. Nitekim Körfez ülkeleri açtıkları okullar, üniversiteler ve medya kanalları vasıtasıyla İslam ülkelerinde önemli bir etki yaratmaya başlamıştır. Bu sayede el-Kaide gibi terör örgütleri ve İhvan gibi İslami siyasetle hareket eden yapılar önemli güç devşirmiştir. ${ }^{58}$ Siyasal İslam'ın yükselmesi Filistin meselesinde Arap milliyetçiliğinin yerini sadece Araplarla sınırlı olmayan bütün İslam âlemini içine alan İslamcı bir bakışın hâkim olmasına neden olmuştur. 2000'lerden itibaren bölgeye Arap olmayan iki yeni gücün dâhil olması yeni bir Ortadoğu yaratmıştır. ${ }^{59}$

1979 İran Devrimi ile birlikte önemli bir kimlik değişimi yaşayan İran, Velâyet-i Fakih yönetimi altında ve Şiî İslam anlayışının kendisine kazandırdığ 1 yeni misyon ile birlikte Şah yönetiminin tam tersi bir şekilde bölge politikasına müdahil olmaya başlamıştır. ABD-İran arasındaki kötü ilişkiler İran dış politikasının daha agresif olmasına ve savunmasını İran dışında başlatmasına neden olmuştur. Eski rejimin aksine yeni rejim, savunmasını dişarıdan başlatmak için bölgede Hizbullah gibi mobilize edebileceği önemli bir Şiî nüfus avantajına sahiptir. Nitekim 1991 ve 2003 ABD müdahaleleriyle Irak'ın zayıflatılması İran'a bölgede etkinliğini artırma imkanı tanımıştır. ${ }^{60}$ Türkiye'nin bölgeye dönüşü ise 1991 Körfez Savaş1

58 Paul Salem, "The Recurring Rise and Fall of Political Islam," içinde Rocky Harbors: Taking Stock of the Middle East in 2015, der. Jon B. Alterman (Center for Strategic \& International Studies: Washington, 2015): 29-38; Raymond Hinnebusch, "The Middle East Regional System," 30-50; Raymond Hinnebusch, The International Politics of the Middle East (Manchester: Manchester University Press, 2004), 39-44.

59 Paul Salem, "The Middle East. Evolution of a Broken Regional Order," Carnegie Middle East Center, no. 9 (Haziran 2008): 1-9.

60 Barış Doster, “Bir Bölgesel Güç Olarak İran'ın Ortadoğu Politikası,” Ortadoğu Analiz 44, (Ağustos 2012): 45-51. 
ve Suriye'nin PKK'ya verdiği destekle başlayan ve 2003'te ABD'nin Irak müdahalesi gibi olaylar sonucunda hem bölge dinamiklerinin hem de yeni bir Kürt jeopolitiğinin oluşmasının sonucudur. Fakat 2002 yılında iktidara gelen AKP hükümeti sahip olduğu İslami kimlik ve bölgenin yeni jeopolitiği nedeniyle Ortadoğu politikasında önemli bir değişim yapmak zorunda kalmıştır. Kendisini artık bir Ortadoğu ülkesi olarak konumlandıran Türkiye, bölge politikalarına daha fazla müdahil olmaya başlamıştır. ${ }^{61} \mathrm{Bu}$ çerçevede 2000 sonrası Yeni Ortadoğu milliyetçiliğin güç kaybettiği, İslamc1 söylemin güç kazandığı bir dönem olarak tezahür etmiştir. Bununla beraber İran'ın dışarıda kaldığı, Türkiye'nin geleneksel Ortadoğu siyasetinden uzak durmayı seçtiği, İsrail düşmanlığı ve Sovyet-ABD politikalarının bölgede temsilciliğini yapan Arap Ortadoğusu olma özelliğini kaybetmiş, İran ve Türkiye'nin bölge siyasetinde aktif rol üstlendiği yeni bir Ortadoğu düzeni ortaya çıkmıştır. ${ }^{62}$

2000'lerin ortalarına kadar ABD'nin bölgede hegemon aktör olarak bölgeyi domine etmesi İran ve Türkiye'nin bölge politikalarında aktif rol oynamasını sınırlandırmıştır. Fakat ABD'nin 2003 Irak müdahalesinin bölgeye getirmiş olduğu ağır yükler, ABD'nin Irak müdahalesi ile oluşturmaya çalıştı̆̆ 1 yeni Ortadoğu düzeni girişiminin ve Arap dünyasını demokratikleştirme sürecinin (en azından şimdiye kadar) başarısız olması, Arap-İsrail barış girişimlerinin başarısızlığ $1, \mathrm{ABD}$ ekonomisinde Ortadoğu petrolünün payının azalması, Irak'ta ortaya çıkan güç boşluğunun yarattı̆̆ 1 Sünni-Şii mücadelesi, Kürt hareketlenmesi, el-Kaide ve diğer terör örgütlerin bölgede güç devşirmeye başlaması bölgesel düzeni ve jeopolitiği etkilemiştir. ${ }^{63}$ Obama döneminden itibaren ABD'nin bölge politikasının yeniden mevzilenme üzerine inşa edilmesi sonucu ortaya çıkan güç boşluğu birçok aktör tarafından doldurulmaya çalışılmıştır. Ayrıca İran'ın bölgede etkinliğinin artması, tepkisel anlamda Suudi Arabistan'ın liderlik ettiği bir Sünni bloğun oluşmasına neden olmuştur.

${ }^{61}$ Bayram Sinkaya, "Geçmişten Günümüze Türkiye'nin Ortadoğu Politikası ve Batı Etkisi," Adam Akademi 1, (2011): 79-100.

62 Paul Salem, "The Middle East. Evolution of a Broken Regional Order," 1-22; Louise Fawcett, "Alliances and Regionalism in the Middle East," içinde International Relations of the Middle East, der. Louise Fawcett (Oxford University Press: Oxford, 2016): 197-217.

63 Itamar Rabinovich, "Israel and the Changing Middle East," Middle East Memo 34 (Ocak 2015), 2. 
2010'un sonlarında Tunus'ta başlayan Arap ayaklanmaları ile birlikte bölgesel düzen güç dengelerinin değişmesi paralelinde şekillenmiştir. Nitekim Arap ayaklanmalarının bölge ülkeleri üzerindeki etkisi üzerine yapılan bütün çalışmalarda Ortadoğu'daki bölgesel düzen değişken, stabil olmayan, devletlerin toprakları üzerindeki egemenliklerini kaybettiği, bölge sınırlarının anlamsızlaştı̆̆ı, güvenliğin olmamasından kaynaklı güvenlik arayışının arttığı, terör örgütlerinin etkin olduğu bir tasvir üzerine inşa edilmektedir. ${ }^{64}$ İsrail ve Suudi Arabistan dahil bölgede pek çok ülkenin hazırlıksız yakalandığı bu yeni durum bölgede güvenlikçi bir perspektifin hakim olmasina neden olmuştur.

Arap ayaklanmaları ile birlikte bölgedeki iç savaşlar, vekalet savaşları Libya, Suriye, Yemen ve Irak gibi birçok bölge ülkesini başarısız devlet statüsüne taşımıştır. Bu durumda birçok bölge devletinin topraklarının bütünlügü ve bu topraklar üzerindeki egemenlikleri tartışmalı hale gelmiştir. ${ }^{65} \mathrm{Bu}$ çerçevede etnik, mezhepsel, sivil, kabilesel ve yabancı güçlerden oluşan pek çok devlet-dışı aktörün şiddet içeren ve politik yollarla teritoryal hakimiyet peşinde koştuğu bir düzen oluşmuştur. Nitekim Libya, Yemen, Irak ve Suriye'de silahlı grupların sınırları aşan İhvan ve muadili İslamcı grupların politik yollarla teritoryal hakimiyet ve egemenlik iddiaları ile politik kurumlar ve hükümetler kurması veya kurma çabası bölgede sadece devlet-toplum ilişkilerini değil aynı zamanda bölge düzenini de değiştirmiştir. Bölgesel anlamda gerçekleşen bu tür değişimler İsrail, Suudi Arabistan, İran ve Türkiye gibi bölgesel aktörlerin bölgeye yönelik daha agresif politikalar yürütmesine neden olmuştur. Türkiye Katar ile birlikte İhvan ve Özgür Suriye Ordusu'nu desteklerken, İran ise Hizbullah ve Husiler gibi Şii grupları desteklemiştir. Türkiye ve İran'ın Suudi Arabistan ve İsrail'in kendisine doğrudan tehdit olarak algıladığ grupları desteklemesi sonucunda İsrail ve Suudi Arabistan, ilk başlarda birbirlerinden ayrı olarak, bölgede İran'ın güç devşirmesine ve İhvan'ın politik güç kazanmasının önüne geçmeye dair politika yürütmüştür. ${ }^{66}$

64 Arap Baharına dair geniş bir analiz için bkz. Nurullah Ardıç, “Arap Baharı'nı Anlamak: Adalet, Onur, Din ve Küresel Siyaset," içinde Türk Dış Politikası Yıllı̆̆ı 2011, der. Burhanettin Duran, Kemal İnat ve Ali Resul Usul (Ankara: SETA Yayınları, 2012): 89-135.

65 Interregnum, 12.

66 Interregnum, 15-16. 
Mısır'da yönetime gelen İhvan'ın askeri darbe ile iktidardan uzaklaştırılmasına ve yeni iktidarı oluşturan Sisi'nin ayakta kalmasına İsrail ve Suudi Arabistan farklı şekillerde destek vermiştir. Suriye'de İran'ın güç kazanmasının önüne geçmek için ikili farklı şekillerde mücadele etmektedir. Özellikle 2015'te ABD'nin İran ile nükleer anlaşmayı imzalaması sonucu güvenlik bağlamında aynı hassasiyetleri paylaşan iki ülke benzer tepkiler vermiştir. Bu çerçeveden bakıldığında İsrail ve Suudi Arabistan'ın bölgede var olan eski statükoyu korumaya veya yeniden tesis etmeye çalıştıkları, Arap ayaklanmaları sonrası aynı olgu ve aktörlerden tehdit algıladıkları ve ABD'nin bölge politikasının nasıl olması gerektiğine dair aynı kanıyı taşıdıkları görülmektedir. ${ }^{67}$ İsrail ve Suudi Arabistan'ın algıladıkları tehditlerin kalıcı olması, Arap ayaklanmalarının bitmemesi, bölgenin halen yeni değişimlere gebe olduğu ve bu değişimlerin İsrail ve Suudi Arabistan için yeni tehdit içerikli problemler yaratacağına dair beklentiler ${ }^{68}$ ile Obama dönemi $\mathrm{ABD}$ politikasının yarattığı güvensizlik gibi faktörler iki ülkenin bölgede oluşmaya başlayan düzeni kendi lehlerine olacak şekilde biçimlendirmek için ikili ilişkilerini daha kalıcı ve kurumsal bir zemine oturtma ihtiyacını ortaya çıkarmıştır. Bu noktada İsrail ve Suudi Arabistan yakınlaşmasını mümkün kılan etkenleri açıklamak, bölgesel düzenin yarattığ sonuçların iki ülke üzerindeki etkisinin ve ilişkilerin gelişimine katkısının daha iyi görülmesini sağlayacaktır.

\subsection{ABD'nin Ortadoğu Politikası ve İran'ın Artan Nüfuzu}

ABD'nin Ortadoğu politikasını farklı dönemde farklı unsurlar etkilemiştir. Soğuk Savaş boyunca bu politikayı Sovyet yayılmacılı̆̆ şsekillendirmiş, Washington bu anlamda Ortadoğu'da komünist bloka karşı ittifaklar inşa etmiş̧ir. Suudi Arabistan, İran, Türkiye ve İsrail bu politikanın en önemli aktörleri olarak görülmüştür. Nixon doktrini ile Suudi Arabistan ve İran ABD'nin bölgedeki en önemli müttefikleri arasında yer alırken 1979 İran devrimi bu süreci yerle bir etmiştir. Devrim öncesi ABD'nin önemli bir müttefiki olan İran devrim sonrasında bölgede ABD karşıtı politikaların

67 Itamar Rabinovich, Israel and Arab Turmoil (2014); Paul Salem, "The Middle East in 2015 and Beyond: Trends and Drives," Middle East Institute Policy Focus Series, Kasim 2014: 1-17.

68 Marwan Muasher, "The Next Arab Uprising: The Collapse of Authoritarianism in the Middle East," Foreign Affairs, Kasım/Aralık, 2018. 
üretildiği merkez konumuna gelmiştir.1979'da yaşanan gelişmeler bölgesel düzenin ve jeopolitiğin değişmesine yol açmıştır. Afganistan'ın Sovyetler Birliği tarafından işgali, İran Devrimi ve Kabe baskını bölgenin stratejik çevresini değiştirmiştir. 1977'de Enver Sedat İsrail meclisi Knesset'te bir konuşma yapmış ve 1979'da Camp David'de İsrail'i tanımıştır. Bu durum İsrail'e karşı direnen Mısır imajını ortadan kaldırarak bir güç boşluğu oluşturmuştur. Bu boşluk İran'ın stratejik planlarıyla doldurulmuş ve 1979 sonrası İran İsrail'e karşı direnen lider ülke olmuştur. ${ }^{69}$

Bu durum Washington'ın Suudi Arabistan'a yönelik politikasını değiştirmiş, Riyad-Washington arasındaki işbirliğini daha da güçlendirilmiştir. Nitekim 1979 sonrası Suudi Arabistan dış politikasında İsrail karşıtlığını yumuşatmış ve İran'ı sınırlandırmayı öncelemiştir. Benzer şekilde Afganistan'da Sovyetlerin tehdit oluşturması da Körfez'in İsrail-Filistin meselesine bakışını etkilemiştir. Öyle ki 1979 öncesi Filistin'e yönelik ekonomik ve siyasal olarak sağlanan destek azaltılarak Afganistan'daki mücahitlere transfer edilmiştir. ${ }^{70}$

Soğuk Savaşın sona ermesiyle birlikte Washington nezdinde bölgede Sovyet tehdidi kalmamasına rağmen İsrail'in güvenliği, enerji güvenliği, hegemonyanın ispatı, "liberal demokrasinin ihracı" gibi birçok sebepten ötürü ABD bölge politikalarını yeniden gözden geçirmiştir. Bu anlamda bölgedeki Saddam gibi revizyonist aktörlerle mücadele ABD'nin birincil önceliği olmuştur. 2000'li yıllarda ABD'nin bölge politikası reaktif ve reaksiyoner bir biçime bürünmüştür. Nitekim 11 Eylül saldırıları ile birlikte ABD Ortadoğu'ya refleks olarak daha fazla askeri müdahalede bulunmuştur. $\mathrm{Bu}$ durum bölgede 1979 'dan beri yükselen İran nüfuzunun giderek artmasına neden olmuştur.

ABD'nin 2003 yılında Irak'ı işgal etmesi ile birlikte Tahran'ın Bağdat'taki nüfuzu gittikçe artmıştır. Özellikle Maliki döneminde bu durum rahatlıkla gözlemlenmektedir. Ayrıca Haşdi Şabi gibi İranlı birçok milisin bünyesinde barındığ 1 oluşumların Irak'ta merkezi yönetime meydan okuması da bu minvalde okunmalıdır. Dolayısıyla ABD'nin bölgeye yönelik askeri müdahaleleri İran'ın elini güçlendirmiştir. Yaklaşık \% 60-65'i Şii olan bir

69 Uzi Rabi ve Chelsi Mueller, "The Gulf Arab states and Israel," 580.

70 "The Gulf States and Israeli- Palestinian Conflict Resolution," Baker Institute Policy Report, Rapor 61, (Eylül 2014), 4. 
Irak'ın işgal edilmesi İran'ın halihazırda elde ettiği gücü daha fazla kurumsallaştırmıştır ve bu durumun sonucunda Suudi Arabistan-İran arasında 1979 yılından beri süren güç mücadelesi daha da şiddetlenmiştir. Kimilerine göre "Soğuk Savaş" olarak adlandırılan bu güç mücadelesinde ${ }^{71}$ Suudi Arabistan birçok aktörle işbirliğine giderek Tahran'ın bölgesel nüfuzunu kırmaya yönelik stratejiler geliştirmiştir. Uzi Rabi ve Chelsi Mueller'in iddiasına göre 2003 Irak işgali sonrası Suudi Arabistan-İran arasındaki Soğuk Savaş'ın artması Suudi Arabistan-İsrail arasındaki güvenlik ve istihbarat alanlarındaki gizli işbirliğini arttırmıştır. ${ }^{72}$ Dolayısıyla Irak'ın ABD tarafından işgali bölgedeki güç dengesini İran lehine değiştirmiştir. İran'ın hız kazanan nükleer çalışmalarının bölgedeki tehdit algılamasını arttırması ile başta Irak ve Lübnan' da Hizbullah olmak üzere İran'ın güçlenmesi ŞiiSünni güç dengesini radikal biçimde değiştirmiştir. Tüm bunlarla beraber İkinci Lübnan savaşında İsrail'in kısmi yenilgisi, Filistin seçimlerinden Hamas'ın galip çıkması ve İsrail açısından radikal grupların lehine işlemesi muhtemel uluslararası ve bölgesel değişimler İsrail tarafından kabul görmeyen Prens Abdullah tarafından sunulan barış girişiminin yeniden gündeme gelip bu defa Riyad'daki Arap Zirvesi'nde 2007'de tekrar kabul edilmesinin yolunu açmıştır. Son tahlilde ABD'nin bölge politikasındaki radikal değişimin işaretleri İran'ın nüfuzunu artırmasına neden olmuştur ve bu durum Suudi Arabistan ve İsrail tarafından şaşkınlık ve kaygıyla karş1lanmıştır. ${ }^{73} \mathrm{Bu}$ anlamda Obama döneminde İran'ın uluslararası ve bölgesel sisteme normal bir devlet olarak entegre edilme çabası İsrail-Suudi Arabistan'1 yakınlaştıran bir gelişme olarak okunabilir. Nitekim Obama dönemi ABD'nin bölge politikası birçok akademisyene göre radikal biçimde değişikliğe uğramıştır. Özellikle 2008'deki ekonomik kriz sonrası ABD'nin bölgeye yönelik bakışı sorgulanmış, bu anlamda ABD izolasyon politikalarını gündeme getirerek bölgedeki düzenin bölgedeki müttefikleri aracılığıyla kurulmasını öncelemiştir. Diğer bir deyişle Obama döneminde ABD'nin bölge politikası bölgesel düzenin kurulması, korunması ve geliştirilmesi noktalarında sorumluluğu müttefiklerine bırakan bir vizyonla şekillenmiştir. Bu durumda Suudi Arabistan ve İsrail artan İran tehdidinin

\footnotetext{
71 Atena Panaite, Cold War in the Middle East: Iran and Saudi Arabia, (Master's Thesis, Miami University, International Relations Department, 2017).

72 Uzi Rabi ve Chelsi Mueller, "The Gulf Arab states and Israel," 576-592.

73 Yoel Guzansky ve Sigurd Neubauer, "Israel and Saudi Arabia,"
} 
bir parametresi olduğu değişen bölgesel düzende gizli bir yakınlaşmaya gitmiştir.

\subsection{Güvenliğin Dönüşümü}

Değişen bölgesel düzenin birinci parametresi olan ABD'nin bölge politikası sonucu bölgedeki birçok devletin yapısı (Irak örneğinde olduğu gibi) değişmiştir. Bölgedeki geleneksel devlet merkezli güvenlik tehditleri devlet dışı aktör merkezli güvenlik tehditlerine evrilmiştir. ABD'nin Obama döneminde olduğu gibi sorumluluk almayarak bölge politikalarına müdahil olmayışı bölgedeki güvenliği ve ittifak zincirlerini etkilemiştir. Örneğin ABD, Suriye'de askeri müdahale seçeneğini kullanmayarak bölgede bir kaos oluşturmuştur. Bu kaos ortamından DAİş gibi terör örgütleri kısa süreliğine fayda sağlarken uzun vadede PYD gibi terör örgütleri Suriye'de kurumsallaşmıştır. Dolayısıyla ABD'nin bölge aktörlerini bölgesel düzenin inşasına dahil etmediği her politika bölgesel düzeni negatif etkilemiştir. Özellikle Arap ayaklanmaları sonrası Libya, Suriye, Yemen gibi birçok ülke başarısız devlet haline gelmiştir. Dolayısıyla 2010 sonrası yeni oluşan Ortadoğu bölgesel düzen ve jeopoliğinde zayıf Arap devletlerin sayıları artmıştır. Söz konusu ülkelerdeki otoriter rejimlerin çökmesi bölgesel düzen açısından önemli işaretler ortaya çıkarmıştır.

Devlet yapılarının zayıflaması, devlet dışı aktörlerin yükselişi ve topraksal taleplerin artı̧̧ ile jeopolitik mücadelenin yeni karakteri Yeni Ortadoğu adı verilen bölgesel düzeni tanımlayan üç sütundur. ${ }^{74}$ Söz konusu yeni bölgesel düzende savaş artık daha melez bir hal almış ve güvenlik paradoksal bir forma bürünmüştür. Özellikle devlet dışı silahlı aktörlerin çökmüş devletlere meydan okumasıyla birlikte yükselen radikalizm Suudi Arabistan gibi monarşileri tedirgin etmiştir. Bu anlamda el-Kaide, DAİş, Husiler gibi devlet dışı silahlı aktörler Suud rejimi için doğrudan güvenlik tehditi oluşturmuştur. İsrail açısından da tehdit olarak görülen bu aktörler Suudi Arabistan-İsrail yakınlaşmasını daha anlamlı kılmaktadır. Dolayısıyla 2010 yılında başlayan Arap ayaklanmaları Ortadoğu'daki düzen ve jeopolitiği sarsmış, Tunus, Mısır ve Libya'daki diktatörlerin iktidardan

74 Murat Yeşiltaş ve Burhanettin Duran, “Ortadoğu'da DDSA'ların Yükselişi," içinde Ortadoğu'da Devlet Dışı Silahlı Aktörler: Terör Örgütleri, Milisler, Vekil Güçler, (der.) Murat Yeşiltaş ve Burhanettin Duran (Ankara: SETA Kitapları, 2018), 9-27. 
uzaklaştırılmasıyla rejim güvenliği konusunda birincil tehditler hisseden Körfez monarşileri İsrail’e yönelik politikalarını tekrar gözden geçirmiştir.

İran'ın Arap ayaklanmalarını 1979 Devrimi ile özdeştirmesi ve medya aracılığıyla Arap monarşilerindeki halkları kışkırtması Suudi Arabistan ve diğer monarşileri İsrail'e yaklaştırmıştır. Nitekim güvenlik bağlamında ABD'ye bağımlı olan bu aktörler Washington'ın Obama dönemi büyük (grand) stratejisine bağlı olarak pasif politikalar izlemesinden oldukça rahatsız olmuştur. Bu durum ilk olarak Suudi Arabistan'ın inisiyatif alarak iddialı bir dış politika izlemesine neden olmuştur. İkinci olarak bölgede İran karşıtı cephenin daha belirgin bir hale gelmesine sebebiyet vermiştir. Bu cephede İsrail, Suudi Arabistan'ın İran ile mücadelesinde önemli bir aktör olarak görülmüştür. Ayrıca Arap ayaklanmaları sonrası değişen bölgesel düzen ve jeopolitik paralelinde Suudi Arabistan başta olmak üzere Körfez ülkelerinin İsrail-Filistin çatışmasına yönelik politikaları değişmiştir. Diğer bir deyişle İsrail-Filistin çatışmasının sonlandırılması ve Ortadoğu barış süreci Suudi Arabistan ve Körfez ülkelerinin dış politika yapımında merkezi olmaktan çıkmıştır. ${ }^{75}$

Arap ayaklanmalarıyla oluşan yeni bölgesel düzen ve jeopolitik İsrail-Suudi Arabistan yakınlaşmasını sağlamıştır. Ortak pozisyon alınan konular arasında İhvan, DAİŞ gibi terör örgütleri ve İran gibi bölgesel statükoya meydan okuyanlar bulunmaktadır. Zikredilen meydan okumalar Suudi Arabistan'ın tehditleri firsatlara çevirmeyi hedefleyen reaktif yönelimli bir dış politika izlemesine yol açmıştır. ${ }^{76} \mathrm{Bu}$ dış politik yaklaşım ve bölgesel statükonun korunması gibi hedefler Suudi Arabistan'ın İsrail ile yakınlaşmasını sağlamıştır. İki ülkeyi yakınlaştıran bölgesel düzen çerçevesinde birçok gelişmeden söz edilebilir. Bunlardan bir diğeri de bölgede artan siyasal İslam ve İhvan'ın nüfuzudur.

75 "The Gulf States and Israeli- Palestinian Conflict Resolution," Baker Institute Policy Report, Rapor 61, (Eylül 2014): 2.

76 Necmettin Acar, “Arap Baharı Sürecinde Ortadoğu'da Güvenlik ve Dış Politika: Suudi Arabistan Örneği," Birey ve Toplum 8, say1. 16 (Güz 2018). 


\section{3. İhvan ve Siyasal İslamın Mobilizasyonu}

2010 sonrası bölgesel düzende siyasal İslam'ın yükselmesi Suudi Arabistan ile İsrail'i yakınlaştıran bir diğer unsurdur. Bu anlamda İhvan ve hareketin bölgesel ölçekteki yansımaları Riyad ve Tel Aviv arasındaki işbirliğini güçlendirmiştir. Dolayısıyla iki ülkenin İhvan'a karşı ittifak yürüttüğü rahatlıkla söylenebilir. ${ }^{77}$ Özellikle Mısır'da Mursi iktidarı ile etkinliği artan İhvan bölgesel düzeni değiştirme potansiyeline sahip bir aktör olarak görülmüştür. İhvan'ın Tunus, Ürdün, Suriye, Libya, Yemen gibi bölgedeki önemli aktörlerin de siyasal yapılarını değiştirme potansiyeli bölge siyasetinde kırılmalara yol açmıştır. Riyad ve Tel Aviv bölgesel düzenin İhvan lehine değişimine karşı pozisyon alarak işbirliğine gitmiştir. Bu noktada iki aktörü yakınlaştıran İhvan karşıtlı̆̆ farklı gerekçelerle açıklanabilir. Riyad'ın İhvan karşıtlığ 1 rejim güvenliği ile alakalandırılırken Tel Aviv'in İhvan karşıtlığ 1 Hamas'ın mobilizasyonu ${ }^{78}$ ile alakalandırılabilir. İki aktörün İhvan'a karşı hamleleri incelendiğinde birçok gelişmeden söz edilebilir. Tel Aviv yönetimi İhvan'ı bölgesel ve küresel ölçekte destekleyen Katar devletinin bir yayın organı olan Al Jazeera ofislerini kapatmıştır. ${ }^{79}$ Benzer bir karar 2017 yılında Suudi yetkililer tarafından alınmıştır. ${ }^{80}$ Öte yandan Suudi Arabistan Mursi karşıtı gösterileri ve 3 Temmuz darbesini siyasal ve finansal yönden açıkça desteklemiştir. ${ }^{81} 2014$ yılında ise Suudi Arabistan yönetimi İhvan'1 terör örgütü listesine alarak ${ }^{82}$ bölgesel düzene meydan okuyan siyasal İslam'ın en önemli temsilcisini bölgesel ve küresel ölçekte sınırlandırmaya çalışmıştır.

Öte yandan ABD Başkanı Trump'ın İhvan'1 terör örgütü ilan etme girişimlerinin de olduğu bilinmektedir. Dolayısıyla Trump yönetiminin Ortadoğu

77 Yoel Guzansky ve Sigurd Neubauer, "Israel and Saudi Arabia."

78 "Islamism after the Arab Spring: Between the Islamic State and the nation-state," The Brookings Project on U.S. Relations with the Islamic World U.S.-Islamic World Forum Papers 2015 (Washington, 2017), 13.

79 "Israel moves to shut Al Jazeera's office and ban journalists," The Middle East Eye, 6 Ağustos 2017.

80 Amanda Erickson, "Why Saudi Arabia hates Al Jazeera s much," The Washington Post, 23 Haziran 2017.

81 İsmail Numan Telci, Mısır: Devrim ve Karşı Devrim (İstanbul: SETA Yayınları, 2017), 21.

82 Ashraf el-Sherif, "The Muslimbrotherhood and the Future of Political Islam in Egypt," Carnegie Endowment for International Peace (Ekim 2014), 5. 
politikasının Suudi Arabistan-İsrail yakınlaşması açısından olumlu etkileri olabilir. İki aktörü yakınlaştıran bölgesel düzenin üç parametresine yönelik Trump'ın söylem ve eylemleri Suudi Arabistan ve İsrail arasındaki işbirliğini yoğunlaştırmaktadır. Örneğin Trump İran ile yapılan nükleer anlaşmadan çekilmiştir. Suudi Arabistan ve İsrail tarafından ortak güvenlik kaygısı olarak görülen İran'a yönelik bu hamle ve Trump'ın ilk yurtdışı ziyaretini Suudi Arabistan'da başlatı İsrail'de sonlandırması Suudi Arabistan ve İsrail yakınlaşmasını hızlandırmıştır ve Trump'ın bu minvalde politikalar izlemesi iki aktörün daha da yakınlaşmasını sağlayabilir. İki ülke arasındaki yakınlaşmanın geleceğine dair konuşulması gereken bir diğer mesele Türkiye-İsrail arasındaki gerginliktir. 2010 sonrası bölgesel düzende meydana gelen değişimler ve yaşanan gelişmeler Türkiye ve İsrail'i farklı kutuplara yerleştirmişti. Bu durumda Türkiye genel hatlarıyla halk ayaklanmalarının yanında bir tutum sergilemiş ve İsrail'in Filistin üzerindeki ihlallerini eleştirmişti. Gelinen noktada iki ülke arasındaki gerginlik gerek Suudi Arabistan-Türkiye ilişkilerini gerekse Suudi Arabistan-İsrail ilişkilerini etkilemiştir. Kaşıç̧ı cinayeti ve Katar ablukası başta olmak üzere birçok meselede görüş farklılığına sahip olan Türkiye ve Suudi Arabistan ilişkileri bin Selman'ın siyaseten aktif olduğu 2015'ten beri oldukça durgun profilde seyretmiştir. Bu durum İsrail-Suudi Arabistan yakınlaşmasını daha mümkün kılmaktadır. Diğer bir deyişle İsrail'in Türkiye ile yaşadığ krizler ve Suudi Arabistan'ın Türkiye ile olan ilişkilerindeki problemler Suudi Arabistan- İsrail arasındaki işbirliğini sağlamlaştırmaktadır. Nitekim iki ülkedeki yönetici elit Türkiye'deki iktidarın değişmesi için ortak çalışmalar yürütmektedir. ${ }^{83}$

\section{Sonuç}

$\mathrm{Bu}$ çalışmada İsrail ve Suudi Arabistan yakınlaşmasının sadece bölgede İran "tehdidinin" yükselmesi ile açıklanamayacağı iddia edilmiştir. Ça1ışmaya göre 2000 sonrası bölgesel düzende meydana gelen değişimlerin ortaya çıkardığı sonuçlar İsrail ve Suudi Arabistan yakınlaşmasını mümkün kılmıştır. Bu çerçevede, İsrail ve Suudi Arabistan yakınlaşmasını sağ-

83 Mehmet Solmaz, "Why Saudi Arabia and the UAE are targeting Turkey," Middle East Eye, 27 Aralık 2017; David Hearst and Ragip Soylu, "EXCLUSIVE: Saudi Arabia's 'strategic plan' to take Turkey down," Middle East Eye, 5 Ağustos 2019. 
layan bölgesel düzendeki değişimler üç temel parametrede özetlenmiştir. Bunlardan ilki ve en önemlisi ABD'nin bölge politikasıyla ilgilidir. Bush ve Obama dönemlerinde Washington'ın izlediği bölge politikası sonucu bölgesel düzen ve güç dengeleri değişmiştir. Özellikle 2003 Irak müdahalesi ve 2015 nükleer anlaşma sonrası İran bölgesel nüfuzunu artırmıştır. Benzer şekilde Obama dönemi ABD büyük stratejisinin ortaya çıkardığ sonuçlar bölgesel ittifakları dönüştürmüştür. Bu minvalde Suudi Arabistan ile İsrail yakınlaşmıştır. Değişen bölgesel düzenin ikinci parametresi ise güvenlik ile alakalıdır. Bu anlamda istikrarlı olmayan devletlerin toprakları üzerindeki egemenliklerini kaybetmeleri, bölge sınırlarının devlet-dışı aktörler tarafından anlamsızlaştırılması ve bölge devletlerinin nispeten güçlü ve merkezi yapılarını kaybetmelerinden kaynaklanan güvenlik problemlerinin artması sonucu aktörler dış politik reflekslerini değiştirmiştir. Bu anlamda DAİş, el-Kaide, İran destekli Husiler ve Hizbullah gibi güvenlik problemleri oluşturan aktörlere karşı Suudi Arabistan ve İsrail işbirliği içerisine girmiştir. Bölgesel düzendeki değişimin üçüncü ve son parametresi olan siyasal İslamcı hareketlerin yükselişi de iki aktörü yakınlaştırmıştır. Bu anlamda İhvan ve muadili İslamcı hareketlerin bölge siyasetinde önemli bir rol oynamaya başlaması İsrail-Suudi Arabistan hattındaki işbirliği işaretlerini daha görünür k1lmaktadır.

\section{Kaynakça}

Abadi, Jacob. "Saudi Arabia's rapprochement with Israel: the national security imperativess." Middle Eastern Studies 55, sayı 3, (2019): 433449.

Abrams, Elliot. "The Saudis and Israel Again," Council on Foreign Relations, 23 Kasim 2017.

Acar, Necmettin. "Arap Baharı Sürecinde Ortadoğu'da Güvenlik ve D1ş Politika: Suudi Arabistan Örneği." Birey ve Toplum 8, sayı 16 (Güz 2018): 139-171.

Ardıç, Nurullah. "Arap Baharı'nı Anlamak: Adalet, Onur, Din ve Küresel Siyaset." İçinde Türk Dış Politikası Yıllı̆̆ 2011, der. Burhanettin Duran, Kemal İnat ve Ali Resul Usul, 89-135. Ankara: SETA Yayınları, 2012. 
Bahgat, Gawdat. Israel and the Persian Gulf: Retrospect and Prospect. Florida: University of Florida, 2006.

Baker Institute Policy Report, Rapor 61, (Eylül 2014).

Black, Ian. "Just Below The Surface: Israel the Arab Gulf States and the Limits of Cooperation." LSE Middle East Centre Report (Mart 2019):1-41.

Bureš, Jaroslav. Main Characteristic and Development Trends of Migration in the Arab World. Prague: Institute of International Relations, 2008.

Çiçekçi, Ceyhun. Arap Baharı Sonrası İsrail Dış Politikası: Kavram, Bağlam, Pratik ve Kuram. İstanbul: Kriter, 2018.

Doster, Barış. "Bir Bölgesel Güç Olarak İran'ın Ortadoğu Politikası." Ortadoğu Analiz 44 (A ğustos 2012): 44-51.

Eisenhower, Dwight D. The White House Years: Waging Peace, a Personal Account 1956-1961, New York: Doubleday \& Company, Inc. 1960.

Eisenhower's Letter to Edward Lee Roy Elson, EM, WHCF, Official File 116-R, 31 July 1958, (der.) Louis Galambos ve Daun Van Ee, içinde The Papers of Dwight David Eisenhower, The Presidency: Keeping the Peace, Vol. XIX (Baltimore, MD: The Johns Hopkins University Press, 2001), Letter \#797, 1027.

el-Sherif, Ashraf. "The Muslimbrotherhood and the Future of Political Islam in Egypt." Carnegie Endowment for International Peace (Ekim 2014).

Erickson, Amanda. "Why Saudi Arabia hates Al Jazeera as much." The Washington Post, 23 Haziran 2017.

Fawcett, Louise. "Alliances and Regionalism in the Middle East." içinde International Relations of the Middle East, (der). Louise Fawcett. Oxford University Press, 2016: 197-217.

Flapan, Simha. The Birth of Israel: Myths and Realities. New York: Pantheon Books, 1987.

Guzansky, Yoel ve Neubauer, Sigurd. "Israel and Saudi Arabia: A Changing Region, a Possible Partnership." The National Interest, 24 Temmuz 2014. 
Harel, Amos. "Israeli Military Chief Gives Unprecedented Interview to Saudi," Haaretz, 17 Kasım 2017.

Hinnebusch, Raymond. "The Middle East Regional System." içinde The Foreign Policies of Middle East States. (der.) Raymond Hinnebusch and Anoushiravan Ehteshami. London: Lynne Rienner Publishers, 2002: 35-74.

Hinnebusch, Raymond. The International Politics of the Middle East. Manchester University Press, 2004.

Interregnum: The Regional Order in the Middle East and Nort Africa: After 2011. MENARA Final Reports, no. 1 (Şubat 2019).

Ismael, Tareq Y. "Regional Dynamics and International Relation in the Middle East." içinde International Relations of the Contemporary Middle East: A Study in World Politics. (der.) Tareq Y. Ismael, Syracuse University Press, 1986.

Kiddie, Nikki R. "Is There a Middle East?." International Journal of Middle East Studies 4, no. 3 (Temmuz 1973): 255-271.

Korany, Bahgat ve Fattah, Moataz A. "Irreconcilable Role-Partners?: Saudi Foreign Policy between the Ulama and the US." içinde The Foreign Policies of Arab States: The Challenge of Globalization, der. Bahgat Korany ve Ali E. Hillal Dessouki. New York\&Cairo: The American University in Cairo Press, 2008.

Kostiner, Joseph. "Saudi Arabia and the Arab-Israeli Peace Process: The Fluctuation of Regional Coordination," British Journal of Middle Eastern Studies 36, say1 3, Aralık 2009.

Mann, Joseph. "The Syrian Neo-Bacth Regime and the Kingdom of Saudi Arabia." Middle Eastern Studies 42, say1 5 (Eylül 2006).

Muasher, Marwan. "The Next Arab Uprising: The Collapse of Authoritarianism in the Middle East." Foreign Affairs, Kasım/Aralık, 2018.

Orkaby, Asher. "Rivals with Benefits: Israel and Saudi Arabia's Secret History of Cooperation.” Foreign Affairs, 13 Mart 2015.

Örmeci, Ozan. "İsrail-Suudi Arabistan Yakınlaşması Gerçeğe Dönüşebilir Mi? Yapısalc1 Realist Bir Analiz." International Journal of Economics, Administrative and Social Sciences (IJEASS) 1, no.1 (2018 Aral1k): 60-100. 
Panaite, Atena. "Cold War in the Middle East: Iran and Saudi Arabia". Master Thesis, Miami University, International Relations Department, 2017.

Piscatori, James P., Ramazani, R.K. "The Middle East." içinde Comparative Regional Systems: West and East Euorope, Nort America, The Middle East, and Developing Countries, der. Werner J. Feld ve Gavin Boyd New York: Pergamon Press, 1980, 274-299.

Quandt, William B. Saudi Arabia in the 1980s: Foreign Policy, Security, and Oil. Washington: Brookings Institution Press,1981.

Rabi, Uzi ve Mueller, Chelsi. "The Gulf Arab states and Israel since 1967: from 'no negotiation' to tacit cooperation." British Journal of Middle Eastern Studies 44, no. 4 (2017): 576-592.

Rabinovich, Itamar. "Israel and the Changing Middle East." Middle East Memo 34 (January 2015): 1-11.

Rabinovich, Itamar. Israel and Arab Turmoil. London: Hoover Institution Press, 2014.

Rieger, Rene. "Saudi Arabia's Relations with Israel and Palestine." içinde Saudi Foreign Policy: Conflict and Cooperation. (der.) Neil Partrick, London: I.B. Tauris, 2016.

Salem, Paul. "The Middle East. Evolution of a Broken Regional Order." Carnegie Middle East Center, no. 9 (Haziran 2008): 1-22.

Salem, Paul. "The Middle East in 2015 and Beyond: Trends and Drives." Middle East Institute Policy Focus Series, Ekim 2014: 1-17.

Salem, Paul. "The Recurring Rise and Fall of Political Islam." içinde Rocky Harbors: Taking Stock of the Middle East in 2015, ed. Jon B. Alterman Center for Strategic \& International Studies: Washington, 2015, 29-38.

Sinkaya, Bayram. "Geçmişten Günümüze Türkiye'nin Ortadoğu Politikası ve Bat1 Etkisi." Adam Akademi 1 (2011): 79-100.

Teitelbaum, Joshua. "Saudi-Israeli Relations: Balancing Legitimacy and Security." BESA Center Perspectives, Paper no. 228 (17 Aralık 2013).

Telci, İsmail Numan. Mısır: Devrim ve Karşı Devrim. İstanbul: SETA Yayınları, 2017. 
Tyler, Patrick. A World of Trouble: The White House and the Middle Eastfrom the Cold War to the War of the Terror. New York: Farrar, Straus and Giroux, 2010.

Weiss, Martin A. “Arab League Boycott of Israel," CRS Report, 25 Ağustos 2017.

Yamani, Mai. “Two Faces of Saudi Arabia." Survival 50, no. 1 (2008).

Yaşar, Fatma Tunç, Özcan, Sevinç Alkan ve Kor, Zahide Tuba. Siyonizm Düşünden İşgal Gerçeğine Filistin. İstanbul: İHH Yayınları, 2010.

Yeşiltaş, Murat ve Duran, Burhanettin. "Ortadoğu'da DDSA'ların Yükselişi,” içinde Ortadoğu'da Devlet Dışı Silahlı Aktörler: Terör Örgütleri, Milisler, Vekil Güçler, der. Murat Yeşiltaş ve Burhanettin Duran. 9-27. Ankara: SETA Kitapları, 2018.

Zahlan, Rosemarie Said. Palestine and the Gulf States.New York: Routledge, 2009.

\section{Internet Kaynakları}

"Ex-Saudi intelligence chief reveals secret Israel-Saudi relations," The Middle East Monitor, 11 Şubat 2019.

"Islamism after the Arab Spring: Between the Islamic State and the nationstate," The Brookings Project on U.S. Relations with the Islamic World U.S.-Islamic World Forum Papers 2015 (Washington, 2017).

"Israel moves to shut Al Jazeera's office and ban journalists," The Middle East Eye, 6 Ağustos 2017.

"Israel said to be working with Saudi Arabia on Iran strike plan," Times of Israel, 17 Ekim 2013.

"Israeli Software Helped Saudis Spy on Khashoggi, Lawsuit Says," The New York Times, 2 Aralik 2018.

"İsrail basını Veliaht Prens Bin Selman>a methiyeler dizdi," Sabah, 23 Ekim 2018.

"Saudi prince in 'secret meeting' with Israeli officials," The New Arab, 10 Eylül 2017. 
"Saudi prince paid secret visit to Israel: Broadcaster," Anadolu Agency, 8 Ağustos 2017.

"Saudi supported Israel against Hezbollah during 2006 war," The Middle East Monitor, 16 Şubat 2019.

"The Gulf States and Israeli- Palestinian Conflict Resolution," Baker Institute Policy Report, Rapor 61 (Eylül 2014).

"Why Saudi Arabia and Israel oppose Iran nuclear deal," Al Jazeera, 14 Nisan 2015. 